\title{
Recorregut de recerca geològica i mineralògica per les comarques del Baix Camp, del Priorat i de la Conca de Barberà: des de Prades al Coll Roig, a Ulldemolins i a Vilanova de Prades
}

Josep Maria Mata-Perelló

Joaquim Sanz Balagué

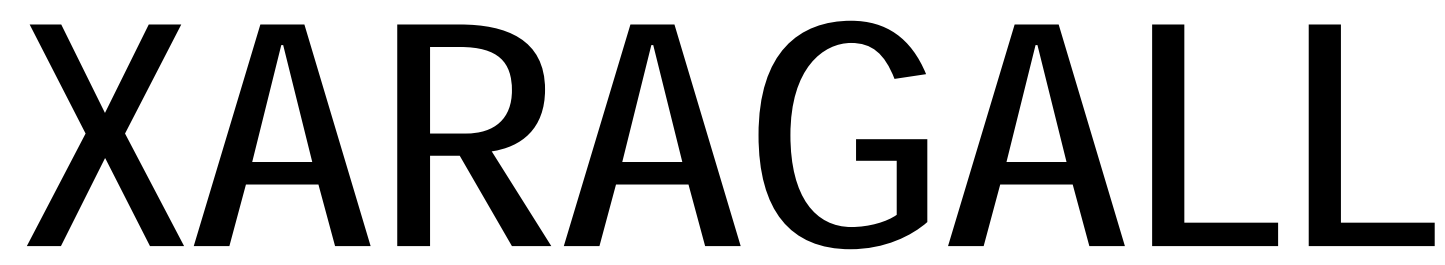

REVISTA DE CIÈNCIES DE LA CATALUNYA CENTRAL

n. 4

ABRIL 2015 


\title{
RECORREGUT DE RECERCA GEOLÒGICA I MINERALÒGICA PER LES COMARQUES DEL BAIX CAMP, DEL PRIORAT I DE LA CONCA DE BARBERÀ: DES DE PRADES AL COLL ROIG, A ULLDEMOLINS I A VILANOVA DE PRADES
}

\author{
Josep Maria Mata-Perelló \\ Museu de geologia Valentí Masachs, Escola Politècnica Superior d'Enginyeria de Manresa \\ (EPSEM), Universitat Politècnica de Catalunya · BarcelonaTech (UPC), 08272 Manresa, Spain
}

\section{Joaquim Sanz Balagué}

Departament d'Enginyeria Minera i Recursos Naturals (EMRN), Escola Politècnica Superior d'Enginyeria de Manresa (EPSEM), Universitat Politècnica de Catalunya - BarcelonaTech (UPC), 08272 Manresa, Spain

Paraules clau: Sistema Mediterrani, Materials mesozoics, Materials paleozoics, Patrimoni miner

\section{Resum}

Itinerari realitzat el 24 de maig de 2014. En aquesta ocasió, el recorregut de l'itinerari discorrerà, en la seva quasi totalitat pel Sistema Mediterrani (més concretament per la Serralada Prelitoral Catalana). Tot i així, en alguns trams ho farà molt prop de la Depressió Geològica de l'Ebre (pel seu sector corresponent a la Depressió Central); inclús i penetrarà lleugerament dintre d'aquesta unitat, pels voltants de les poblacions d'Ulldemolins i de Vilanova de Prades.

Així, dintre de la primera unitat geològica, es transitarà quasi al llarg de tot el recorregut, entre Prades i les immediacions del Coll Roig. A partir d’aquí, s'anirà sempre per les immediacions del contacte entre aquesta unitat geològica i l'esmentada Depressió Geològica de l'Ebre; i tal com s'ha dit, en alguns trams es transitarà per aquesta unitat geològica.

Per altra banda, la totalitat del recorregut s'haurà desenvolupat per la Regió de Reus, iniciantse a la comarca del Baix Camp (a la població de Prades). Després, el recorregut entrarà a la comarca del Priorat (per on es transitarà entre Albarca, Ulldemolins i la carretera a Vilanova de Prades). Finalment, s'entrarà a la comarca de la Conca de Barberà (per on finalitzarà el recorregut de l'itinerari, prop de Vilanova de Prades). 


\section{Objectius fonamentals}

Els objectius fonamentals que es pretenen aconseguir en aquest itinerari, es poden concretar en els següents aspectes generals:

1. Estudi i observació de la Serralada Prelitoral Catalana (integrada dintre del Sistema Mediterrani), per la qual discorrerà el recorregut de l'itinerari entre els voltants de Prades i d'Ulldemolins. Tanmateix, es transitarà per aquesta unitat geològica pels voltants de Vilanova de Prades., per on finalitzarà, camí de Prades.

2. Reconeixement dels materials paleozoics (amb esquistos, pissarres i quarsites del Carbonífer; així com per afloraments de roques granítiques i granodiorítiques) i del mesozoics (exclusivament del Triàsic, amb trams de calcàries, gresos i calcolutites). que constitueixen la Serralada Prelitoral Catalana , per aquests indrets per on transcorre l'itinerari.

3. Estudi i observació de la Depressió Central Catalana (la qual forma part de la Depressió Geològica de I'Ebre). Aquesta unitat la tallarem entre les poblacions d'Albarca i Ulldemolins. I més endavant també pels voltants de Vilanova de Prades, cap als darrers trams del recorregut del present itinerari.

4. Observació i descripció dels materials terciaris (del paleogen), i dels quaternaris que sovint els cobreixen. Uns i altres reblen la Depressió Geològica de l'Ebre, tot formant el Complex $d^{\prime}$ Ulldemolins (pel que fa als cenozoics). Tots aquests materials s'aniran trobant a diferents indrets del recorregut: Albarca, Ulldemolins i Vilanova de Prades.

5. Observació de les estructures locals d'aquests materials, al llarg del recorregut de I'itinerari, i del contacte entre la Serralada Prelitoral Catalana i la Depressió Geològica de l'Ebre; i més concretament entre la vorera septentrional de la Taula de Prades, la Serra de la Llena i el Montsant.

6. Observació i reconeixement de diferents mineralitzacions situades a diferents indrets del recorregut de l'itinerari, d'acord amb l'ordre del seu recorregut, com les següents:

6A) les mineralitzacions evaporítiques guixoses, situades per diferents indrets, com prop d'Ulldemolins, (dintre de la comarca del Priorat). Localitzant-se entre els afloraments terciaris de la Depressió Geològica de l'Ebre.

6B) formacions diagenètiques de sílex, associades a les anteriors, que trobarem als mateixos indrets que aquelles, especialment a Ulldemolins (Priorat).

6C) de les mineralitzacions filonianes de fluorita situades a la Mina de Sant Antoni, al terme de Ulldemolins (Priorat), dintre de la Serralada Prelitoral Catalana.

6D) de les mineralitzacions estratiformes de $P b-Z n-C u$, situades al terme de Vilanova de Prades (Conca de Barberà), dintre de la Serralada Prelitoral Catalana.

6D) i de les mineralitzacions filonianes de $\mathrm{Cu}$, situades al terme de Vilanova de Prades (Conca de Barberà), dintre de la Serralada Prelitoral Catalana.

7. Visió de les diferents explotacions dels georrecuros situats al llarg del recorregut de l'itinerari, relacionades amb les explotacions de les diferents mineralitzacions esmentades a l'apartat anterior. 
8. Observació de les tasques de restauració dutes a terme sobre les explotacions anteriors, per tal de reduir l'impacte ambiental de les mateixes. O si s'escau de les restauracions espontànies produïdes.

9. Observació dels indrets relacionats amb el nostre Patrimoni Geològic i Miner, que trobarem al llarg del recorregut de l'itinerari. Com és el cas de la Font Major de l'Espluga de Francolí i les anomenades Crestes del Blai o la Flexura del Montsant (dintre del patrimoni geològic), o de les diferents explotacions mineres que trobarem (dintre del patrimoni miner).

\section{Antecedents}

Pel que fa al recorregut del present itinerari, existeixen uns antecedents nostres, de tipus bibliogràfic referents a la totalitat del recorregut del mateix. Es tracta de MATA-PERELLÓ (1996, 1997a, 1997b, 1997c, 1997d, 1998, 2000, 2001, 2002a, 2002b, 2004, 2011, 2012a i 2012b) i de MATA-PERELLÓ i COLLDEFORNS (1994 i 1996).

Pel que fa a la descripció de les mineralitzacions d'aquesta comarca, cal parlar dels treballs de MATA-PERELLÓ (1991), relatiu a les mineralitzacions catalanes en general; i també dels de MELGAREJO (1992), centrat en els materials i les mineralitzacions del paleozoic, de les comarques del Baix Camp, de la Conca de Barberà i del Priorat

Per altra banda, i pel que fa a les característiques dels materials geològics, farem esment de dos treballs; concretament de: GUIMERÀ et altri (1982) i de RIBA et altri (1976). Tanmateix farem esment dels treballs de I'IGME (1973a i 1973b).

Tots aquests treballs referenciats, i d'altres, figuren esmentats per ordre alfabètic a l'apartat dedicat a la BIBLIOGRAFIA.

\section{Recorregut de l'itinerari}

El recorregut del present itinerari s'iniciarà a la localitat de Prades, per on es farà la primera aturada. Tot seguit, el recorregut es dirigirà cap a les immediacions d'Albarca, seguint la carretera local T - 701. En aquest tram s'efectuaran diverses aturades. En aquest tram, passarem de la comarca del Baix Camp a la del Priorat.

Després, es continuarà per la carretera comar C - 242, anant-se cap a les immediacions del poble d' Ulldemolins. Abans d'arribar-hi es farà una nova aturada. Per d'altra banda, prop del poble, sortint cap el NW, es faran diverses aturades.

Finalment, el recorregut es dirigirà cap el Nord i després cap a l'Est, seguint primer la carretera comarcal C - 242 i despès la local TV - 7004, la qual va conduint cap el poble de Vilanova de Prades. En aquest tram del recorregut es faran diverses aturades. En aquest tram passarem de la comarca del Priorat a la de la Conca de Barberà.

I, finalment, a la sortida del darrer poble esmentat, es farà la parada final sobre la carretera local TV - 7005, la qual condueix cap a Prades. 


\section{Advertiments previs}

Com en altres recorreguts de RECERCA GEOLÒGICA I MINERALÒGICA... si es disposa del temps suficient, poden efectuar-se passant per totes les parades i filloles. En cas contrari, recomanem prescindir de les anomenades PARADES - CONDICIONALS.

Per altra banda, alhora de fer el recorregut de l'itinerari, cal cercar abans tota la informació necessària, per tal de conèixer l'estat dels vials per on s'haurà de circular als diferents trams del recorregut de l'itinerari.

Cal tenir una cura molt especial de respecte a la natura, al llarg de tot el recorregut; de l'itinerari.

\section{Descripció de l'itinerari}

Com en altres itineraris, aquest s'estructurarà en una sèrie de PARADES o d'ESTACIONS que anirem veient a continuació. continuació. En cada una d'aquests aturades es farà un breu comentari. Per d'altra banda, darrera del nom de l'indret situarem (entre parèntesi) el número del full del Mapa Topogràfic, a escala 1:50.000, on es troba situat. En aquest itinerari, utilitzarem els següents fulls: 417 (o de I'Espluga de Francolí) i $\mathbf{4 4 5}$ (o de Cornudella). A continuació, començarem la descripció de les diferents aturades que formen part del present recorregut.

\subsection{Parada 1. LA PLAÇA MAJOR DE PRADES, (terme municipal de Prades, comarca del Baix Camp). (Full 445).}

El recorregut de l'itinerari, el començarem en aquest indret, de la població de Prades, situada dintre de la comarca del Baix Camp

Aquest indret es troba situat dintre de la Serralada Prelitoral Catalana, entre afloraments dels materials triàsics del Buntsandsteim, tot i que molt propers als afloraments dels materials carbonífers del Paleozoic. De fet, prop del poble s'observen abundants afloraments de granits i de granodiorites.

Precisament, a l'indret on ara som, trobarem que aquests materials triàsics, són els que han estat utilitzats per a la construcció de l'Església i de moltes de les edificacions del poble de Prades, especialment de la plaça i de la porta d'entrada a la població, situada al costat de l'església. Així veurem que per arreu hi ha carreus dels gresos rogencs del Buntsandstein, tot i que també es fan palesos els gresos clars. (fotografia 1). 


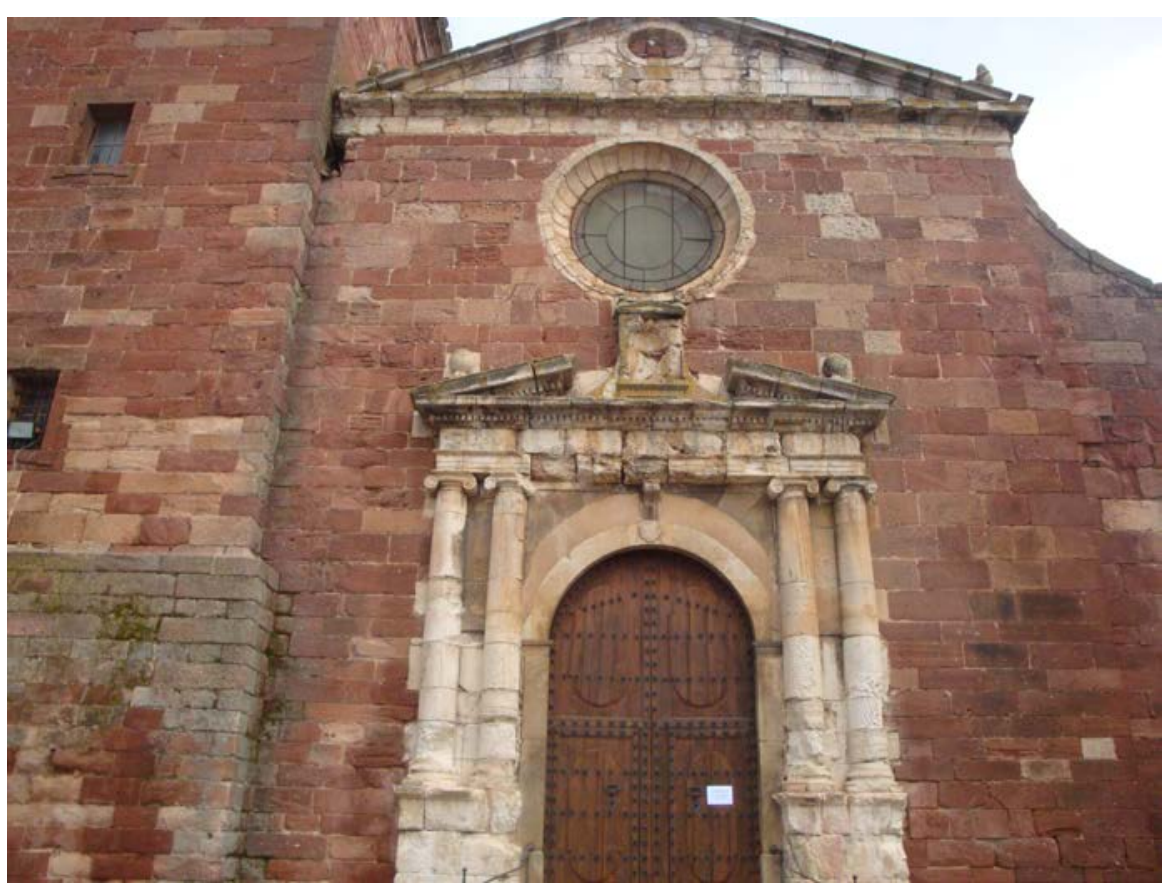

Fotografia 1. Façana de l'església de Prades, amb carreus dels materials del Buntsandsteim.

\subsection{Parada 2. COLL ROIG, CARRETERA A PRADES, (Albarca, terme municipal de Cornudella del Montsant, comarca del Priorat). (Full 445).}

Després de realitzar l'aturada anterior, ens caldrà agafar la carretera que es dirigeix cap a Albarca (la T- 701). Així, agafant aquesta carretera, en uns $7 \mathrm{Km}$ arribarem al Coll Roig, per on farem una nova aturada de l'itinerari.

En aquest recorregut, hem anat trobant inicialment els materials triàsics del Buntsandstein. Tot $\mathrm{i}$ així, ben aviat hem començat a trobar afloraments dels materials esquistosos del Carbonífer. És a dir, ens hem desplaçat dintre de la Serralada Prelitoral Catalana. Tot i així, en arribar al coll hem trobat afloraments de les lutites rogenques, les quals pertanyen al Complex d'Ulldemolins, del cenozoic.

En aquest coll es troba el contacte per falla entre els nivells eocènics del Complex d'Ulldemolins (situats a la Depressió Geològica de l'Ebre) i les pissarres del Carbonífer (que pertanyen a la Serralada Prelitoral Catalana). Finalment, cal dir que el topònim "Coll Roig" al-ludeix a la presencia d'uns estrats de color rogenc. Són els que hem esmentat anteriorment del Complex d'Ulldemolins.

Aquesta fractura, segueix cap al Sud, discorrent pel Barranc de l'Argentera, cap I'embassament de Cornudella, per on hi ha diverses mineralitzacions de $\mathrm{Pb}-\mathrm{Zn}$, amb GALENA ARGENTÍFERA. 


\subsection{Parada 3. ANTIGUES EXPLOTACIONS DE GUIX, Km 35 de la carretera comarcal C-242, (terme d'Ulldemolins, comarca del Priorat). (Full 445).}

Després de fer l'aturada anterior, cal anar cap el proper Coll d'Albarca. Des d'aquí, ens caldrà continuar per las carretera comarcal C-242, tot anant cap al poble d'Ulldemolins. En arribar a les immediacions del seu $\mathrm{Km} 35$ (a uns $2 \mathrm{Km}$ abans d'arribar al poble i a uns $5 \mathrm{Km}$ del coll), cal fer la present aturada, a una antiga guixera situada a la dreta de la carretera. Així, des de la darrera aturada, haurem recorregut uns $6 \mathrm{Km}$, aproximadament.

En tot aquest recorregut, hem continuant trobant afloraments dels materials abans esmentats del Complex d'Ulldemolins; és a dir: haurem estat circulant per la Depressió geològica de I'Ebre; tot i que molt a prop de la Serralada Prelitoral Catalana. Per d'altra banda, en aquesta part del recorregut, cada cop hem anat trobant més afloraments dels nivells dels materials guixosos, els quals es troben inclosos en aquest complex de l'Eocè Inferior. Aquests són els materials que predominen a l'indret de la present aturada.

En aquest indret, i sobre aquests nivells es van realitzar diverses explotacions de GUIX. Una d'aquestes guixeres es troba molt a prop de la carretera, en el seu Km 35, per la qual cosa es de molt fàcil accés. Així, aquí es pot fer una bona observació d'aquests materials. Malgrat això, cal tenir cura de possibles despreniments, doncs els nivells guixosos es troben intensament fracturats. (fotografía 2)..

Per altra banda, cal fer esment de d'abundant presència de nombrososi nòduls de SILEX (QUARS), entre els nivells de guixos, la qual cosa es fa força evident en aquests pedrera.

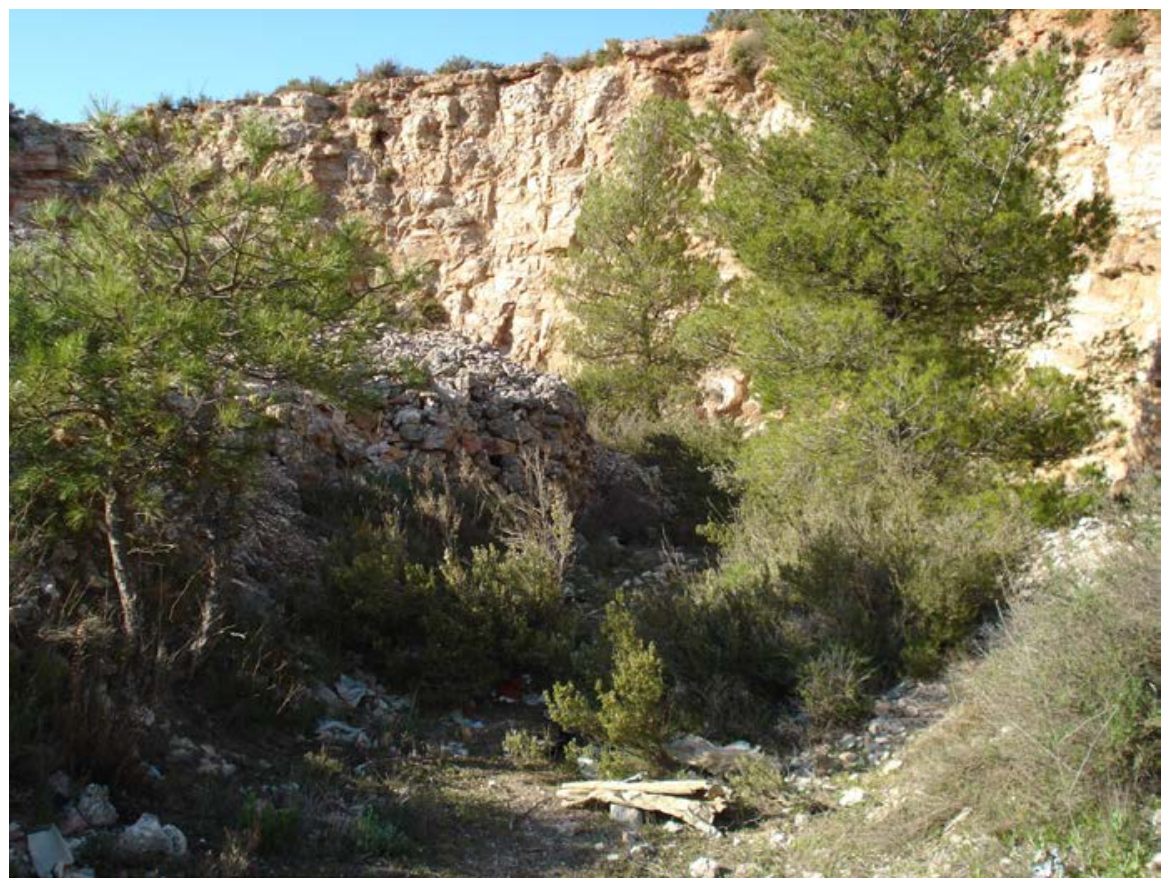

Fotografia 2. Aspecte de la guixera d’'Ulldemolins 


\subsection{Parada 4. MINES DE FLUORITA DE SANT ANTONI, (terme municipal d'Ulldemolins, comarca del Priorat). (Full 445).}

Després de fer la parada anterior, cal continuar, per tal d'arribar a Ulldemolins, que caldrà sobrepassar. En arribar al pont sobre el Riu Montsant, és necessari agafar un camí que surt de I'altra banda del riu. Des d'aquí és necessari continuar a peu. A uns $150 \mathrm{~m}$. del seu inici es troba una mina de fluorita. En total, s' haurà efectuat un recorregut proper als $8 \mathrm{Km}$, des de la parada anterior.

Tot aquest recorregut s'efectua, com abans, prop del contacte entre la Serralada Prelitoral Catalana (on es troben tant la parada precedent, com la present), i la Depressió Geològica de I'Ebre, per on discorre la major part del recorregut entre ambdues parades, per entre els materials de la Formació Montsant.

En el recorregut, des del pont, es van tallant nivells de lutites (amb nòduls de QUARS, en forma de "chert", SÍLEX), que pertanyen a l'Eocè Inferior, i que corresponen al Complex $d^{\prime}$ Ulldemolins. Prop de la mina es comencen a trobar els nivells d'esquists, que pertanyen al Carbonífer; és a dir: hem entrat de nou a la Serralada Prelitoral.

La mineralització, on es troba situada la mina, és de caràcter filonià, i es troba encaixada entre uns afloraments de pòrfirs granítics, que travessen aquests materials paleozoics del Carbonífer acabats d'esmentar. FOTOGRAFIA 3.

Entre els minerals presents, cal fer esment dels següents: CALCOPIRITA, ESFALERITA, GALENA, MARCASSITA, FLUORITA (és el mineral més important, i que va ésser motiu d'explotació), CALCITA, BARITINA i QUARS (molt abundant).

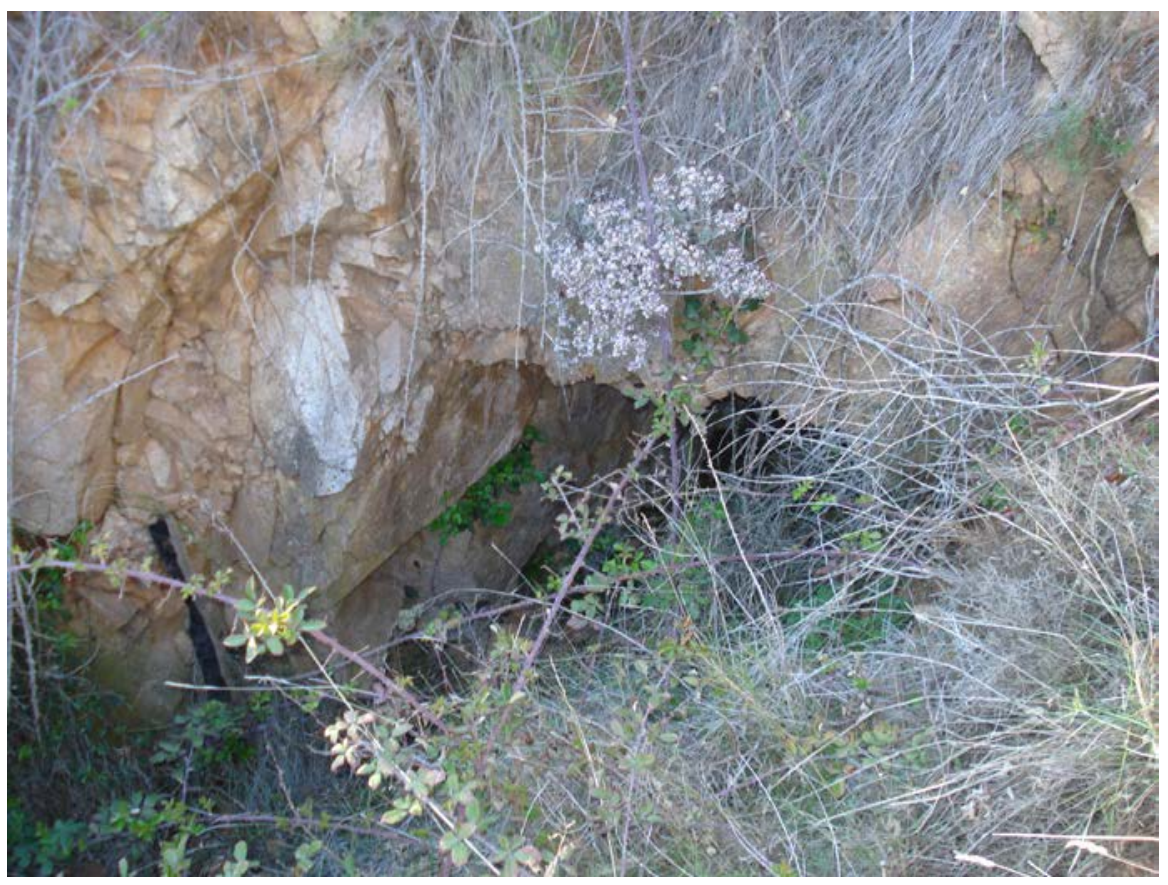

Fotografia 3. Bocamina de les Mines de Sant Antoni 
Tots aquests minerals es poden trobar solament a les escombreres, ja que es pràcticament impossible de penetrar dintre de la mina, per trobar-se totalment inundada a l'actualitat. Malgrat això la fluorita és l'únic mineral fàcilment trobable entre els derrubis de l'escombrera, ja que els altres són força minoritaris.

També, cal dir que a poca distància d'aquesta mina, se'n troba una altra a la qual es pot arribar fàcilment (PARADA 4-BIS). Per fer-ho, cal remuntar el Riu Montsant, per la mateixa vorera de la mina. A $1 \mathrm{~km}$., aproximadament es troba aquesta altra. A diferència del cas anterior, en aquesta es pot penetrar sense cap mena de dificultat.

Tant en una mina com en I'altra, es poden trobar cristalls de FLUORITA relativament grans $i$ bonics. En la primera tenen un intens color groc, i són més petits. A la segona poden arribar a tenir fins a $15 \mathrm{~mm}$. d'aresta, però no són tant vistosos.

\subsection{Parada 5. LES CRESTES DEL BLAI, CARRETERA C-242, (terme municipal d'Ulldemolins, comarca del Priorat). (Full 445).}

Des de la parada anterior, cal retornar a la carretera C-242, per tal de continuar en direcció cap a les terres de Lleida. Així, aviat es deixarà enrere la carretera que es dirigeix cap a Vilanova de Prades (la TV-7004).

Més endavant s'arribarà a l'indret on farem la present aturada, situat molt a prop de la cruïlla d'on eix la carretera que es dirigeix cap a la Pobla de Cérvols. Així, just a la darrera corba farem la present aturada, després de recórrer uns 3-34’ $5 \mathrm{Km}$, des de la parada anterior.

En aquest recorregut, hem retornat de nou a la Depressió Geològica de I'Ebre, on ara ens trobem situats, entre afloraments terrígens de tonalitats groguenques, els quals pertanyen a la Formació Margalef.

En aquest indret, i mirant cap al SW, es possible d'observar les anomenades Crestes del Blai, situades a l'extrem septentrional del Montsant, a la vorera esquerra del riu del mateix nom que l'esmentada serra. Es tracta d'una discordança entre els materials de la Formació Montsant, que constitueixen la "Flexura del Montsant". (fotografía 4). 


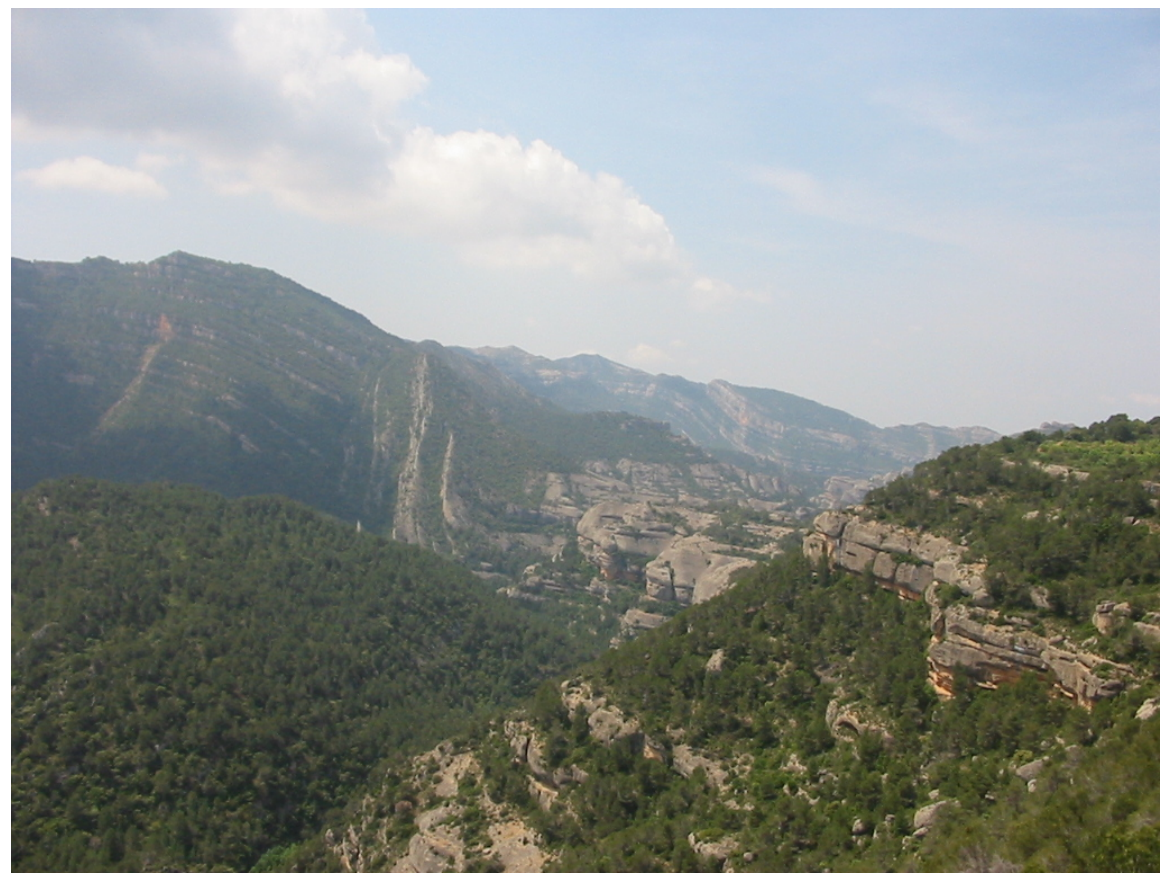

Fotografia 4. Aspecte de la Flexura del Montsant

\subsection{Parada 6. CARRETERA D’ULLDEMOLINS A VILANOVA DE PRADES, IMMEDIACIONS DEL Km 4’2, MINES DEL BESSÓS, (termes municipals de Vilanova de Prades i d'Ulldemolins, comarques de la Conca de Barberà i del Priorat, respectivament, (Full 417).}

Des de la parada anterior, cal tornar lleugerament cap enrere, per tal d'agafar la carretera TV7004, per tal d'anar a les immediacions del seu Km 4'2, tot anant cap a llevant. Des d'aquest indret, parteix un camí per la dreta que condueix en $1 \mathrm{~km}$. fins a la vora del Riu Montsant, on es troben aquestes mines. Així, des de la parada anterior, haurem recorregut uns $12 \mathrm{Km}$ més.

Tot aquest recorregut s'efectua, per la Depressió Geològica de l'Ebre, per entre els materials de la Formació Montsant. Tot i així, els darrers trams d'aproximació a les mines, s'hauran fet entre afloraments dels materials paleozoics de la Serralada Prelitoral Catalana, on estem ara situats.

Pel que fa a les mines, cal dir que es troben situades a les dues ribes de riu abans esmentat, $i$ localitzades sobre unes mineralitzacions estratiformes, desenvolupades entre els materials esquistosos del Carbonífer, els quals es troben en contacte amb nivells de gresos (també del Carbonífer), amb intercalacions de nivells de calcosquistos, i amb la presència de nivells clorítics (d'un intens color verd). Per d'altra banda també cal esmentar la presència de pòrfirs granítics, els quals es troben en contacte amb els materials anteriors. Tanmateix, part de l'aflorament té un clar aspecte de skarnoide.

Entre els minerals presents, cal fer esment dels següents: CALCOPIRITA (molt abundant), ESFALERITA (és el mineral més abundant, conjuntament amb el següent), GALENA (és el mineral més representatiu), MARCASSITA, PIRITA, ANQUERITA i QUARS. També es troben indicis, generalment en forma molt testimonial de GREENOCKITA, MAGNETITA i SCHEELITA. 
Entre els minerals d'alteració, cal fer esment dels següents: GOETHITA (molt abundant, limonítica), ATZURITA, CERUSSITA, HIDROCINCITA, MALAQUITA, SIDERITA, ORICALCITA i SMITHSONITA. Tots aquests minerals són en general poc abundants (tret dels dos primers $\mathrm{i}$ de la malaquita).

Finalment, també es pot fer esment de la presència de dendrites de PIROLUSITA. Altres minerals presents, localitzats entre les roques acompanyants són els següents: CALCITA, DOLOMITA, CLORITA (molt abundant, sense identificar), EPIDOTA i GRANAT.

Malgrat I'abundor d'espècies minerals, difícilment es poden trobar tots ells a les escombreres 0 als afloraments, per tal d'identificar-los de "visu", i solament es fa clarament palesa la presència dels següents minerals (d'acord amb l'ordre de les relacions anteriorment donades): calcopirita, esfalerita, galena, pirita, anquerita, quars, goethita, atzurita, pirolusita, malaquita i clorita, entre altres.

Finalment, cal dir que sobre aquestes mineralitzacions es van situar unes antigues explotacions de $\mathrm{Pb}-\mathrm{Zn}-\mathrm{Cu}$, que molt recentment van ésser recercades de nou, durant la dècada dels setanta, per la Real Compañia Asturiana de Zinc. Així, es fàcil trobar restes dels antics testimonis extrets durant les prospeccions.

\subsection{PARADA 7. CARRETERA D'ULLDEMOLINS A VILANOVA DE PRADES, IMMEDIACIONS DEL Km 6’4, (terme municipal de Vilanova de Prades, comarca de la Conca de Barberà). (Full 417).}

Des de la parada anterior, cal tornar cap a la carretera TV-7004, per tal de continuar cap a llevant, fins a les immediacions del seu Km 6'4. Aquí cal prendre l'antiga carretera, i a uns 200 $\mathrm{m}$. de prendre-la, en una corba de la mateixa, es troba un caminet que condueix a la vella mina de baritina, en un trajecte d'uns $30 \mathrm{~m}$. Així, des de la parada anterior, s' haurà fet un recorregut molt proper a $4 \mathrm{Km}$.

En aquest breu recorregut, s'ha circulat preferentment per entre els materials detrítics de la Formació Montsant, dintre de la Depressió Geològica de l'Ebre, però sempre molt a prop del seu contacte amb la Serralada Prelitoral Catalana, en la qual afloren uns nivells esquistosos, amb freqüents intrusions granítiques, del Carbonífer. Després, en apropar-nos cap a la mina, hem penetrat dintre de la segona unitat geològica acabada d'esmentar.

La mina es troba situada sobre una mineralització filoniana, encaixada entre els materials granítics. Malgrat això, no és possible veure el filó, per trobar-se enfonsada la mina. Entre els minerals es fàcilment observable la BARITINA, la qual es troba acompanyada de GALENA (indicis), i de QUARS. (MATA-PERELLÓ, 1991). Tot i així, els més abundants són el primer (el qual es va intentar d'explotar) $\mathrm{i}$ el tercer.

\subsection{Parada 8. CARRETERA DE VILANOVA DE PRADES CAP A PRADES, IMMEDIACIONS DEL SEU Km 1, (terme de Vilanova de Prades, comarca de la Conca de Barberà). (Full 417).}

Després de la parada anterior, cal arribar a Vilanova de Prades, tot seguint la carretera TV7004. Després, en arribar al poble, caldrà agafar el trencall de la carretera local TV-7005, la qual es dirigeix cap a Prades, per tal de fer una petita fillola, i efectuar una parada prop del $\mathrm{Km}$ 1 , després d'efectuar un recorregut proper als $3 \mathrm{Km}$, des de la parada anterior.

En aquest recorregut, hem anat circulant inicialment per entre els materials terciaris del Complex Al.luvial del Montsant, i més concretament els nivells bassals de la Formació 
Montsant. Aquests materials, eminentment detrítics, de tonalitats clarament ocre-groguenques a la base, pertanyen a la Depressió Geològica de l'Ebre.

Tot i així, en agafar la carretera que se'n va cap a Prades hem passat a la Serralada Prelitoral Catalana, i ara ens trobem front a un dipòsit de roques granítiques molt alterades. Aquestes roques han estat explotades en aquest indret on ara som.

Entre aquestes roques, s'hi observen alguns filonets cuprífers (de QUARS-CALCOPIRITA). Tot i així, es fan força paleses les alteracions dels sulfurs de coure, amb la presència d'ATZURITA, i sobretot de MALAQUITA, que es troben abundantment entre els derrubis.

Des d'aquest indret, i mirant cap al NW, es pot veure una bona panoràmica de la Depressió Geològica de l'Ebre, i dels seus contactes amb la propera Serralada Prelitoral Catalana, on ara ens trobem. Tanmateix, es pot veure un tall complementari del que hem vist a la parada anterior.

En aquest indret finalitza el recorregut de l'itinerari

\section{Bibliografia}

GUIMERÀ, J. et altri /1992).- Geologia (HI), Història Natural dels Països Catalans, Vol., 547 pag. Enciclopèdia Catalana, SA, Barcelona.

IGME (1973a).- Mapa Geológico de España (2a Sèrie). Explicación de las Hoja $n^{\circ} 418$ (Montblanc). Inst. Geol. Min. España. Minist. Indústria. Madrid.

IGME (1973b).- Mapa Geológico de España (2a Sèrie). Explicación de las Hoja nº 446 (Valls).. Inst. Geol. Min. España. Minist. Indústria. Madrid.

MATA-PERELLÓ, J.M. (1991).- Els Minerals de Catalunya. Institut d'Estudis Catalans. Arxius de la Secció de Ciències, T.XLVIII, 506 pag. Barcelona.

MATA-PERELLÓ, J.M. (1996).- Itinerari geològic i mineralògic per les comarques del Priorat i del Baix Camp: des de Reus a Cornudella del Montsant, per Prades. Inèdit, 12 pàgines. Manresa.

MATA-PERELLÓ, J.M. (1997a).- Recerca geològica i mineralògica per les comarques del Priorat i del Baix Camp: des de Reus i de I'Aleixar, a les Borges del Camp i a Ulldemolins. Algeps, sèrie $\mathrm{B}, \mathrm{n}^{\circ} 47,14$ pàg. Manresa.

MATA-PERELLÓ, J.M. (1997b).- Recerca geològica i mineralògica per les comarques del Priorat i del Baix Camp: des de Reus i de l'Aleixar, a les Borges del Camp i a Ulldemolins. Inèdit, 14 pag. Manresa.

MATA-PERELLÓ, J.M. (1997c).- Recorregut de recerca geològica i mineralògica per les comarques de les Garrigues i de la Conca de Barberà. Inèdit, 14 pàg. Manresa.

MATA-PERELLÓ, J.M. (1997d).- Recerca geològica i mineralògica per la Conca de Barberà, pel Priorat i per les Garrigues: des de Sarral a Vimbodí i d'Ulldemolins a Margalef i a la Pobla de Cérvoles. Xaragall, sèrie $B, n^{\circ}$ 99, 16 pàg. Manresa.

Xaragall.2015 n.4 | Recorregut de recerca geològica i mineralògica per les comarques del Baix Camp, del Priorat i de la Conca de Barberà: des de Prades al Coll Roig, a Ulldemolins i a Vilanova de Prades 
MATA-PERELLÓ, J.M. (1998).- Recerca geològica i mineralògica per les comarques del Baix Camp i del Priorat: des de les Borges del Camp a Prades; i del Coll d'Albarca a Cornudella de Montsant. Xaragall, sèrie $B, n^{\circ} 100,18$ pàg. Manresa.

MATA-PERELLÓ, J.M. (2000).- Recorregut de recerca geològica i mineralògica per les comarques del Baix Camp i del Priorat: des de les Borges del Camp a Cornudella del Montsant i a la Pobla de Cérvoles Xaragall, sèrie $B, n^{\circ} 127,14$ pàg. Manresa.

MATA-PERELLÓ, J.M. (2001).- Recorregut de recerca geològica i mineralògica per la vorera del Montsant: des de la Venta del Pubill i Cornudella del Montsant a Ulldemolins. Inèdit, 12 pag. Manresa.

MATA-PERELLÓ, J.M. (2002a).- Recorr, de recerca geològica i mineralògica per la comarca del Priorat: des de Porrera a Cornudella del Montsant i a Ulldemolins. Inèdit, 10 pàgines. Manresa.

MATA-PERELLÓ, J.M. (2002b).- Recorregut de recerca geològica i mineralògica per les comarques del Priorat i de la Conca de Barberà: des de Porrera a Cornudella del Montsant, a Ulldemolins i a Vimbodí. Inèdit, 12 pag. Manresa.

MATA-PERELLÓ, J.M. (2004).- Recorregut de recerca geològica i mineralògica per les comarques del Priorat i de la Conca de Barberà: des de Cornudella del Montsant, a Ulldemolins, a Vallclara i a Vimbodí. Inèdit. 12 pag. Manresa.

MATA-PERELLÓ, J.M. (2011).- Recorregut de recerca geològica i mineralògica per les comarques del Baix Camp, del Priorat i de la Conca de Barberà: des de Prades al Coll Roig, a Ulldemolins, Vallclara i a Vimbodí. Inèdit. 8 pàgines. Manresa.

MATA-PERELLÓ, J.M. (2012a).- Recorregut de recerca geològica i mineralògica per les comarques de la Conca de Barberà, del Baix Camp i del Priorat: des de l'Espluga de Francolí a Prades al Coll Roig, a Ulldemolins, Vallclara i a Vimbodí. Inèdit. 12 pàgines. Manresa.

MATA-PERELLÓ, J.M. (2012b).- Recorregut de recerca geològica i mineralògica per la comarca del Baix Camp: pels voltants de Prades. Inèdit. 6 pàgines. Manresa.

MATA-PERELLÓ, J.M. i COLLDEFORNS, B. (1994).- Itinerari geològic i Mineralògic des d'Ulldemolins a les Borges del Camp. Inèdit, 12 pàgines. Manresa.

MATA-PERELLÓ, J.M. i COLLDEFORNS, B. (1996).- Itinerari geològic i mineralògic per la Conca de Barberà, pel Priorat i per la Ribera d’Ebre: des de Vimbodí a Ulldemolins i a Mora d’Ebre, Inèdit, 12 pag. Manresa.

MATA-PERELLÓ, J.M. i MONTANÉ GARCÍA, P. (1996).- Recorregut de recerca geològica i mineralògica per les comarques del Priorat y de la Conca de Barberà: des del Coll d'Albarca a Ulldemolins, a Vallclara i a Vimbodí. Inèdit. 10 pàgines. Manresa.

MELGAREJO,J.C. (1992).- Estudio geológico y metalogenético del paleozoico del sur de las Cordilleras Costeras Catalanas. Memórias dels Instituto Tecnológico y Geo-Minero de España, tomo 103, 605 pag. Madrid.

RIBA, O. et altri (1976).- Geografia Física dels Països Catalans. Edit. Ketres, 254 pàgines. Barcelona. 